\title{
Prepartum nutritional strategy affects reproductive performance in dairy cows
}

\author{
F. C. Cardoso, ${ }^{*}$ S. J. LeBlanc, † M. R. Murphy, ${ }^{*}$ and J. K. Drackley ${ }^{* 1}$ \\ *Department of Animal Sciences, University of Illinois, Urbana 61801 \\ †Department of Population Medicine, Ontario Veterinary College, University of Guelph, Guelph, ON, Canada N1G 2W1
}

\begin{abstract}
Negative energy balance during early postpartum is associated with reduced reproductive performance in dairy cows. A pooled statistical analysis of 7 studies completed in our group from 1993 to 2010 was conducted to investigate the association between prepartum energy feeding regimen and reproductive performance. The interval from calving to pregnancy (days to pregnancy, DTP) was the dependent variable to assess reproductive performance. Individual data for 408 cows (354 multiparous and 54 primiparous) were included in the analysis. The net energy for lactation $\left(\mathrm{NE}_{\mathrm{L}}\right)$ intake was determined from each cow's average dry matter intake and calculated dietary $\mathrm{NE}_{\mathrm{L}}$ density. Treatments applied prepartum were classified as either controlled-energy (CE; limited $\mathrm{NE}_{\mathrm{L}}$ intake to $\leq 100 \%$ of requirement) or high-energy (HE; cows were allowed to consume $>100 \%$ ) diets fed during the far-off (FO) or close-up (CU) dry periods. Cow was the experimental unit. The Cox proportional hazard model revealed that days to pregnancy was shorter for CE (median $=157 \mathrm{~d}$ ) than $\mathrm{HE}($ median $=167 \mathrm{~d}$ ) diets during the $\mathrm{CU}$ period [hazard ratio $(\mathrm{HR})=0.70$ ]. Cows fed $\mathrm{HE}$ diets during the last 4 wk prepartum lost more body condition score in the first 6 wk postpartum than those fed CE diets $(-0.43$ and -0.30 , respectively). Cows fed $\mathrm{CE}$ diets during the FO period had lower nonesterified fatty acids concentrations in wk 1, 2, and 3 of lactation than cows fed HE diets. Higher nonesterified fatty acids concentration in wk 1 postpartum was associated with a greater probability of disease $(\mathrm{n}=251$; odds ratio $=1.18)$. Cows on the $\mathrm{CE}$ regimen during the $\mathrm{FO}$ period had greater plasma glucose concentrations during wk 1 and 3 after calving than cows fed the HE regimen. Higher plasma glucose (HG) concentration compared with lower glucose (LG) in wk 3 (HG: $\mathrm{n}=$ 154; LG: $\mathrm{n}=206$ ) and wk 4 (HG: $\mathrm{n}=71$; LG: $\mathrm{n}=$ 254) after calving was associated with shorter days to
\end{abstract}

Received March 5, 2013.

Accepted May 18, 2013.

${ }^{1}$ Corresponding author: drackley@illinois.edu pregnancy (wk 3: median $=151$ and $171 \mathrm{~d}$ for HG and $\mathrm{LG}$, respectively, and $\mathrm{HR}=1.3$; wk 4 : median $=148$ and $167 \mathrm{~d}$, respectively, and $\mathrm{HR}=1.4$ ). In the first 2 wk after calving, cows that received $\mathrm{HE}$ diets in the FO period had higher concentrations of total lipids and triglyceride and greater ratio of triglyceride to glycogen in liver than cows fed CE diets. In conclusion, cows fed $\mathrm{CE}$ diets during the $\mathrm{CU}$ period had a shorter interval between parturition and conception, which may be explained by increased $\mathrm{NE}_{\mathrm{L}}$ intake during the first $4 \mathrm{wk}$ postpartum and lower incidence of peripartal diseases. Lower body condition score loss during the first $6 \mathrm{wk}$ postpartum and slightly higher glucose concentration at wk 3 likely contributed to improved reproductive performance.

Key words: transition diet, energy intake, days to pregnancy, controlled energy

\section{INTRODUCTION}

Reproductive performance is a major reason for premature culling of dairy cows, having a great effect on lifetime milk production of individual cows (Beever, 2006). Reproductive inefficiency also reduces the number of calves born, which decreases the number of replacements available (Gröhn and Rajala-Schultz, 2000) and further increases the economic losses caused by infertility. Reproductive efficiency in dairy cattle is commonly well below economic targets not only in the United States but also in Ireland, United Kingdom, and Australia (Lucy, 2001).

An index used to measure infertility in dairy herds is days to pregnancy (DTP), defined as the time in days from calving to the last breeding in which the cow became pregnant. Because conception does not necessarily occur at the first breeding, cows may have to be inseminated more than once. Feed intake and feeding behavior during the transition period may be related to increased risk for uterine diseases in dairy cattle (Urton et al., 2005; Hammon et al., 2006; Huzzey et al., 2007). Hammon et al. (2006) observed that cows developing uterine disease postpartum experienced decreased DMI beginning $1 \mathrm{wk}$ before parturition. In 
concordance, cows diagnosed with severe metritis after calving were already consuming less DM 2 wk before calving (Huzzey et al., 2007). Excessive plasma concentrations of NEFA and BHBA, which are higher in cows experiencing stronger negative energy balance (NEB), are negatively associated with the developmental capacity of oocytes (Leroy et al., 2005) and pregnancy rates (Walsh et al., 2007). Cows with low BCS at $65 \mathrm{~d}$ postpartum are more likely to be anovular (Santos et al., 2008), which can compromise pregnancy success at first postpartum insemination.

Negative energy balance is associated with infertility in dairy cows (Jorritsma et al., 2003). Cows are typically unable to achieve the necessary DMI to maintain energy balance in early lactation (Bauman, 2000). Negative energy balance results from a mismatch between the rapid increase in energy requirements at the onset of lactation and the rate of increase in DMI (Butler, 2000). Negative energy balance suppresses pulsatile LH secretion and reduces ovarian responsiveness to LH stimulation, both of which result in reduced fertility (Butler, 2000). Negative energy balance may begin just before calving, reaches its nadir about $2 \mathrm{wk}$ after calving, and on average lasts until approximately 6 wk postpartum (Butler and Smith, 1989; Bell, 1995; Grummer, 2008). The key determinant of the severity of NEB is DMI in early lactation (Lucy, 2001; NRC, 2001). Feeding strategies in the dry period have as a primary objective to maximize DMI in early lactation.

Based on previous reports (Kunz et al., 1985) and on field observations, our group has been motivated to better understand the possible effects of controlled energy feeding during the transition period. The strategy developed was to formulate and feed diets with relatively low energy density (1.30 to $1.38 \mathrm{Mcal}$ of $\mathrm{NE}_{\mathrm{L}} / \mathrm{kg}$ of $\mathrm{DM}$ ) during the entire dry period. The incorporation of low-energy ingredients (straw or lowquality grass hays) allows cows to consume feed for ad libitum intake without exceeding their daily energy requirements (Janovick and Drackley, 2010). Benefits of feeding controlled-energy ( $\mathbf{C E}$ ) diets prepartum to dairy cows have been reported (Beever, 2006; Dann et al., 2006; Douglas et al., 2006; Janovick and Drackley, 2010). Recently, Janovick et al. (2011) suggested that cows fed CE diets during the dry period had fewer diseases and disorders than cows fed high-energy $(\mathbf{H E})$ diets ( $>100 \%$ of $\mathrm{NE}_{\mathrm{L}}$ requirement). Feeding $\mathrm{HE}$ diets demonstrated that cows can overconsume energy relative to their energy requirement, independent of diet adjustments (Dann et al., 2006; Janovick and Drackley, 2010).

Also, Beever (2006) and Colman et al. (2011) stated that farmers have repeatedly observed easier calving and greater DMI around parturition when energy intake is controlled prepartum. Excess energy consumption prepartum also seems to result in a larger decrease in DMI prepartum compared with cows having CE diets prepartum (Janovick et al., 2011). Such steep changes in DMI prepartum have been associated with increased deposition of lipid in liver postpartum (Drackley et al., 2005). Restricted DMI prepartum was associated with a greater rate of increase and higher DMI postpartum (Douglas et al., 2006; Janovick and Drackley, 2010). Nevertheless, the effect of energy intake prepartum on reproductive performance in dairy cows is still to be assessed. Previous experiments did not have the statistical power necessary to explore such relationships.

The objectives of this study were to examine the associations between feeding $\mathrm{CE}$ or $\mathrm{HE}$ diets during the dry period and the interval to pregnancy in dairy cows. The effects of prepartum dietary energy regimen on BCS, $\mathrm{NE}_{\mathrm{L}}$ intake $\left(\mathbf{N E}_{\mathrm{LI}}\right)$, concentrations of glucose, insulin, and NEFA in blood, and concentrations of total lipids, triglyceride (TG), and glycogen also were determined. Our hypothesis was that cows fed the CE regimen would have more favorable metabolic health in the transition period and, consequently, shorter DTP. Data from several similar experiments were pooled to investigate these associations.

\section{MATERIALS AND METHODS}

\section{Database Construction and Data Collection}

The database was developed from 7 experiments completed at the University of Illinois (Urbana) from 1993 to 2010 (Table 1). Individual cow experimental data were obtained from Microsoft Excel (Microsoft Corp., Redmond, WA) files from each experiment. Individual cow data for management, health, and reproduction were obtained from PCDART herd management software (Dairy Records Management Services, Raleigh, $\mathrm{NC}$ ) or individual cow record cards. A total of 408 cows (354 multiparous and 54 primiparous) were included in the analyses.

Prepartum treatments were defined as follows: (1) HE, where cows were allowed ad libitum access to moderate-energy diets that would allow cows to exceed $\mathrm{NRC}$ requirements $(\mathrm{NRC}, 2001)$ for $\mathrm{NE}_{\mathrm{L}}$, and (2) $\mathrm{CE}$, where cows either were fed restricted amounts of moderate-energy diets to target $\mathrm{NE}_{\mathrm{L}}$ intakes of $80 \%$ of NRC requirements or were allowed ad libitum access to high-fiber, low-energy diets to limit $\mathrm{NE}_{\mathrm{L}}$ intake to approximately $100 \%$ of NRC requirements.

Parity was dichotomized as cows starting first or second lactation in one group (LAG1) and cows in the third-or-greater lactation in a second group (LAG2). In addition, calving season (winter: December to 
Table 1. Experiments from which data were used in a pooled analysis to examine the association of dietary energy density in the dry period with reproductive performance in the following lactation

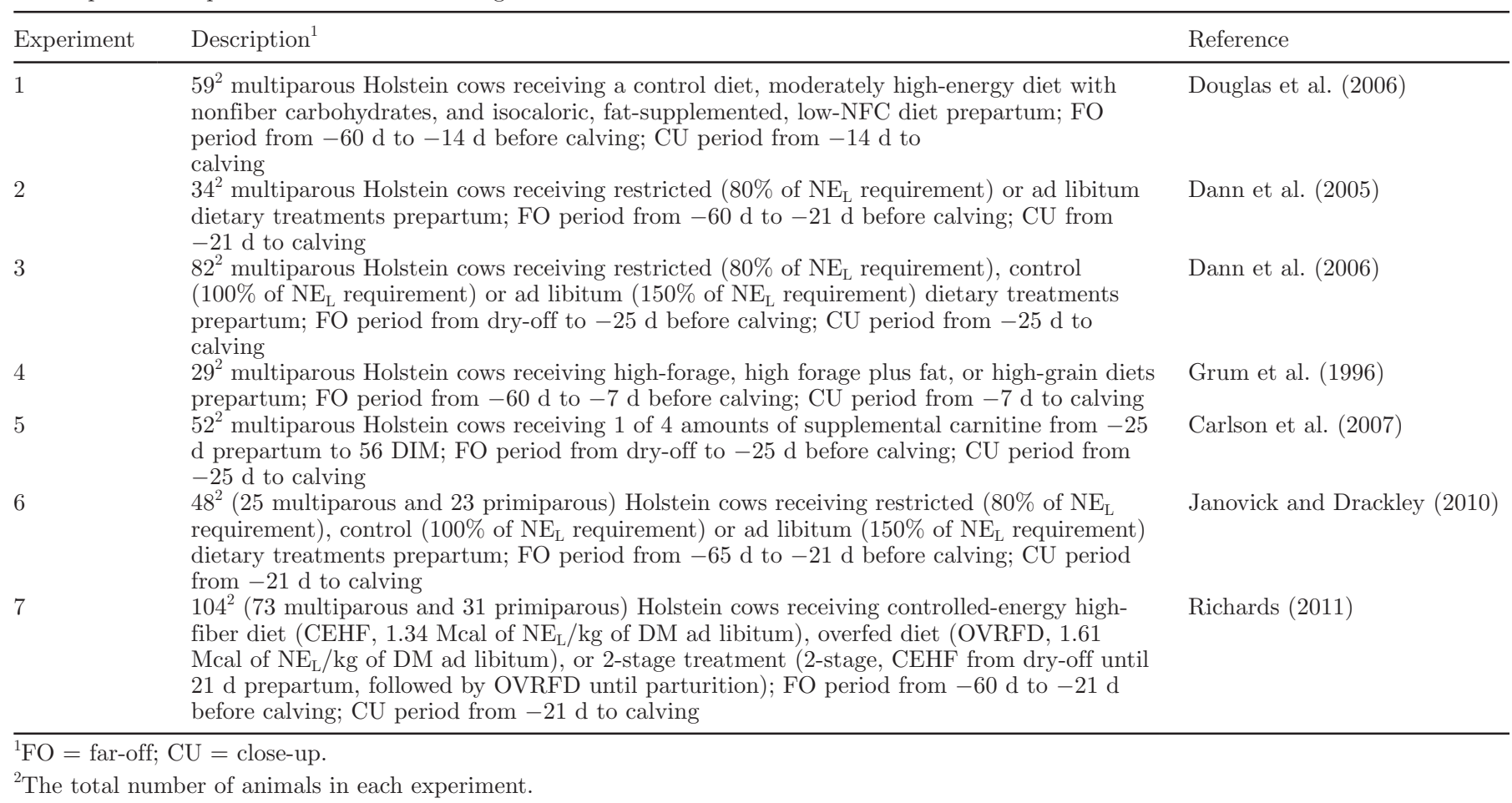

February, spring: March to May, summer: June to August, and autumn: September to November), and twin births, dystocia, and clinical disease occurrence (DISE) were included in the database. Diseases and disorders included were retained placenta, ketosis, uterine prolapse, digestive problems, displaced abomasum, ovarian cyst, and metritis. Diseases and disorders were diagnosed by the research staff and herd veterinarian. If cows had more than 1 DISE, they were classified as having multiple diseases (MDISE). At least 1 occurrence of retained placenta, metritis, or cystic ovary was grouped as the explanatory variable reproductive pathology (RPAT).

Body condition score was assigned independently by more than 1 individual weekly using a 5-point scale (Ferguson et al., 1994) and the median score was used for each cow. Weekly BCS was used either as a continuous variable or was classified as thin $(\mathrm{BCS} \leq 2.75)$, moderate $(\mathrm{BCS} \geq 3$ but $\leq 3.75)$, or fat $(\mathrm{BCS}>3.75)$.

Dry matter intake was recorded daily for individual cows and weekly means by cow were used in the database. Dietary $\mathrm{NE}_{\mathrm{L}}$ density varied from 1.21 to 1.73 Mcal $/ \mathrm{kg}$ of $\mathrm{DM}$ across experiments. The $\mathrm{NE}_{\mathrm{LI}}$ was calculated from the average DMI and the respective dietary $\mathrm{NE}_{\mathrm{L}}$ density. The close-up $(\mathbf{C U})$ period (Table 1) included a negative DCAD diet that was fed during the last $3 \mathrm{wk}$ prepartum in some treatments in all experiments, except that of Grum et al. (1996).
Blood was sampled at different times prepartum and postpartum among experiments. Weekly means were established for the blood metabolites and its sample size is indicated further in the respective analysis. The blood metabolites analyzed were NEFA (Johnson and Peters, 1993) in all experiments; glucose (Trinder, 1969) by kit no. 315 (Sigma, St. Louis, MO) in experiments 1 and 4 and by glucose/HK kit (Roche Diagnostics Corp., Indianapolis, IN) using the glucose-6-phosphate dehydrogenase reaction (Peterson and Young, 1968) in experiments 2, 3, 5, 6, and 7; and insulin by RIA (Coat-a-Count insulin kit; Diagnostic Products Inc., Los Angeles, CA) as modified by Studer et al. (1993) in experiments $1,2,3,4,6$, and 7 . When of interest, the NEFA concentration was dichotomized as high or low using a cut-off value of $700 \mu \mathrm{Eq} / \mathrm{L}$ during wk 1 as defined by Ospina et al. (2010) and glucose concentration was categorized at the median concentration values of $60 \mathrm{mg} / \mathrm{dL}$ at wk 3 and $65 \mathrm{mg} / \mathrm{dL}$ at wk 4 as high (HG) or low $(\mathbf{L G})$. Even though dichotomization can reduce total information, this strategy allowed us to explore the nonlinear association of plasma glucose concentrations throughout lactation that have reduced variation in dairy cows (Herbein et al., 1985).

Puncture biopsy of liver was performed under local anesthesia to obtain approximately 3 to $5 \mathrm{~g}$ of liver tissue (Hughes, 1962; Drackley et al., 1991; Douglas et al., 2004) at d -65 (experiments 1, 2, 3, and 6), 
-30 (experiments 2 and 3 ), -21 (experiments 1,4 , and 5 ), and -14 (experiments $2,3,6$, and 7 ) relative to expected parturition, and at d 1 (experiment 7), 10 (experiments 5 and 7), 14 (experiments 2, 3, and 6), 21 (experiments 1 and 4), 28 (experiments 2, 3, 5, and 6), 42 (experiments 2, 6, and 7), 49 (experiment 3), 60 (experiment 4), and 65 (experiment 1) after calving. Tissue was frozen immediately in liquid $\mathrm{N}_{2}$ until analysis for contents of total lipid (Drackley et al., 1991) and glycogen (GLY; Lo et al., 1970). Total lipids were extracted from liver tissue by using a hexane and isopropanol (3:2) mixture as described by Hara and Radin (1978). Triglyceride was analyzed in the lipid fraction according to established methods (Fletcher, 1968; Foster and Dunn, 1973). Total lipids and TG were kept as continuous variables after calving due to lack of a considerable range in the values among cows. The ratio between liver TG and GLY concentrations was named TG:GLY.

\section{Animals and Housing}

All experimental procedures were conducted according to protocols approved by the University of Illinois Institutional Animal Care and Use Committee. Before calving, cows were housed either in freestalls with individual Calan feed gates (American Calan Inc., Northwood, $\mathrm{NH}$ ) or in tie-stalls. Approximately $2 \mathrm{~d}$ before expected parturition, cows were moved to individual maternity pens until parturition. After parturition, cows were returned to a tie-stall. When housed in tiestalls, cows were allowed to exercise daily for 2 to $3 \mathrm{~h}$ in an outside lot. Cows were milked twice daily. During lactation, all cows received the same diet within experiment (except experiment 5, in which cows were fed different amounts of supplemental carnitine until 56 d postpartum; Table 1). Reproductive management consisted of a voluntary waiting period of $40 \mathrm{~d}$ until first insemination in experiments 1 and 4, synchronized based on $\mathrm{PGF}_{2 \alpha}$ injections. Experiments 2, 3, 5, 6, and 7 had a voluntary waiting period of $60 \mathrm{~d}$. First service was synchronized based on the Presynch protocol (2 doses of $\mathrm{PGF}_{2 \alpha} 14 \mathrm{~d}$ apart; Moreira et al., 2001) and Ovsynch protocol (1 dose of GnRH, 7 d later 1 dose of $\mathrm{PGF}_{2 \alpha}$, and $2 \mathrm{~d}$ later another dose of GnRH; Pursley et al., 1995) and subjected to a timed AI. All cows were bred through AI. Reproductive management remained constant within experiment.

\section{Statistical Analysis}

A final data set including all the variables was constructed in SAS (version 9.2; SAS Institute Inc., Cary, NC). Statistical analyses were performed using the PROC GLIMMIX, MIXED, and PHREG of SAS, considering cow as the experimental unit.

The relationship between prepartum dietary energy content $\left(\mathrm{NE}_{\mathrm{L}}\right)$ and the interval from calving to first AI was explored as a possible confounding factor for treatment effects. The first outcome of interest was the relationship between prepartum $\mathrm{NE}_{\mathrm{L}}$ and the DTP. The secondary outcome of interest was the relationship between prepartum dietary regimen and variables reflecting the physiological status of the animal (e.g., blood metabolites, liver composition, and DISE). The statistical analysis was performed in a hypothesisdriven segmented scheme.

First, a Cox proportional hazard model (PROC PHREG) was used to assess DTP in a survival analysis where experiments were treated as strata to adjust for the random effect of experiment (Gröhn et al., 1998; StPierre, 2001; Allison, 2010). Treatment effects [i.e., CE and HE diets during far-off (FO) or CU periods] were forced into the model and the interaction of dietary energy with time period was included when statistically significant $(P<0.1)$. When statistically significant, the covariates parity, RPAT, and calving season were included in the model. A manual backward stepwise elimination of these variables and their interactions with diet treatments was used when $P \leq 0.05$. A final model was built for the outcome of interest (DTP) and each predictor of interest and week. Parity, RPAT, and calving season were retained as covariates in separate models for the predictor variables glucose, insulin, liver total lipid, and liver TG concentration. The covariates RPAT and calving season remained in the models for the predictor variables liver total lipid concentration in wk -3 and TG concentration in wk -3 . The covariate RPAT was used in the models for the predictor variables liver lipid concentration in wk 4, TG concentration in wk 2 and 4, and TG:GLY throughout. The model considered reproductive data from 10 to $400 \mathrm{~d}$ postpartum. The assumption of the proportionality of hazard of the model was assessed graphically by plotting the logarithm of the hazard function by the logarithm of time. Residuals were evaluated for homogeneous distribution.

Second, once associations were established between prepartum dietary treatments and DTP, a linear mixed model (PROC MIXED) was constructed to explore associations between $\mathrm{FO}$ and $\mathrm{CU}$ feed regimens and BCS, DMI, and plasma NEFA, insulin, and glucose concentrations, and liver total lipid, TG, and glycogen concentrations, and liver TG:GLY. Treatment variables were forced into the model. The covariates parity and calving season, as well as their interactions with treatment, were left in the model when $P \leq 0.05$. Parity was used as a covariate in separate models for the predictor variables NEFA (wk -1 and 1), glucose, 
Table 2. Dry period energy intakes and diet particle size distribution from 7 experiments on prepartum dietary energy density and intake from a total of 408 pregnant Holstein cows ${ }^{1}$

\begin{tabular}{ccccc}
\hline & & \multicolumn{3}{c}{ PSSB $(\% \pm \mathrm{SD})^{4}$} \\
\cline { 3 - 5 } Item $^{2}$ & $\begin{array}{c}\mathrm{NE}_{\mathrm{LI}}{ }^{3} \\
(\text { Mcal/d; mean } \pm \mathrm{SD})\end{array}$ & $>19 \mathrm{~mm}$ & $8-19 \mathrm{~mm}$ & $<8 \mathrm{~mm}$ \\
\hline $\mathrm{FO}$ & & & & \\
$\mathrm{HE}$ & $20.2 \pm 6.8$ & & & \\
$\mathrm{CE}$ & $12.1 \pm 4.2$ & & \\
$\mathrm{CU}$ & $19.8 \pm 6.8$ & $6.44 \pm 1.3$ & $43.08 \pm 1.3$ & $50.48 \pm 3.1$ \\
$\mathrm{HE}$ & $12.1 \pm 4.7$ & $21.8 \pm 2.6$ & $35.2 \pm 1.7$ & $43 \pm 1.4$ \\
$\mathrm{CE}$ & & & & \\
\hline
\end{tabular}

${ }^{1}$ Individual cow DMI was measured daily and diet energy and particle size distribution were measured weekly. ${ }^{2} \mathrm{FO}=$ far-off period; $\mathrm{CU}=$ close-up period; $\mathrm{HE}=$ high-energy diet; $\mathrm{CE}=$ controlled-energy diet.

${ }^{3}$ Net energy for lactation intake $\left(\mathrm{NE}_{\mathrm{LI}}\right.$; diet $\left.\mathrm{NE}_{\mathrm{L}} \times \mathrm{DMI}\right)$ based on the median for each value during the $\mathrm{FO}$ and CU segments of the dry period.

${ }^{4}$ Mean and SD of distribution of TMR particle sizes from samples taken weekly, assessed with the Penn State Particle Separator (PSSB; Pennsylvania State University, University Park) from experiments 3, 6, and 7 (see Table 1).

insulin (wk 1 and 2), total lipid (wk 1 and 2), and TG (wk 1 and 2) concentration. Experiment was considered a random effect (St-Pierre, 2001). Degrees of freedom were estimated by using the Kenward-Roger method (Littell et al., 2002) in the model statement. Residual distribution was evaluated for normality and homoscedasticity and variables were transformed if necessary. A logarithmic transformation was used for the variables NEFA, insulin, total lipid, TG, and GLY concentration for better homogeneity of the distribution of residuals. Means shown in tables for these variables are back transformed.

Third, the metabolite and liver variables found to be associated with prepartum dietary treatments in the mixed models were further investigated as predictors of DTP in Cox proportional hazard models as described above.

Finally, multivariable logistic mixed models (PROC GLIMMIX) considering the binary outcome variables twins, dystocia, DISE, and MDISE were constructed. Prepartum dietary treatments were forced into the models. Experiment was considered as a random effect (St-Pierre, 2001). Parity and calving season were included as covariates in the model when $P \leq 0.05$. Parity and calving season were retained as covariates for DISE, MDISE, and twins; only calving season was used for dystocia.

\section{RESULTS}

A summary of the prepartum CE and HE dietary treatments fed during the $\mathrm{FO}$ and $\mathrm{CU}$ periods is shown in Table 2. For all 408 cows across the 7 experiments, mean $( \pm \mathrm{SD})$ values of milk production, $3.5 \% \mathrm{FCM}$, and BW at wk 4 postpartum were $34.9 \pm 7.6,35.9 \pm 9.0$, and $607 \pm 75 \mathrm{~kg}$, respectively. The Cox proportional hazard model stratified by experiment revealed no sig- nificant difference in days to first AI between cows (n = 332) fed $\mathrm{HE}$ compared with $\mathrm{CE}$ diets during the FO period (median $=88$ and $95 \mathrm{~d}$, respectively; hazard ratio $(\mathbf{H R})=0.959 ; 95 \% \mathrm{CI}=0.6$ to $1.4 ; P=0.84$ ) or cows $(\mathrm{n}=332)$ fed HE compared with $\mathrm{CE}$ diets during the $\mathrm{CU}$ period (median $=95$ and $86 \mathrm{~d}$, respectively; HR $=1.075 ; 95 \% \mathrm{CI}=0.7$ to $1.6 ; P=0.72)$.

The outcome of interest (DTP) analyzed with the Cox proportional hazard model (Table 3) stratified by experiment revealed no significant difference between cows $(\mathrm{n}=332)$ fed HE compared with $\mathrm{CE}$ diets during the FO period (median $=164$ and $165 \mathrm{~d}$, respectively; $\mathrm{HR}=1.229 ; 95 \% \mathrm{CI}=0.8$ to $1.8 ; P=0.29)$. In contrast, cows fed $\mathrm{HE}$ rather than $\mathrm{CE}$ diets during the $\mathrm{CU}$ period had a significantly longer interval to pregnancy $($ median $=167$ and $157 \mathrm{~d}$, respectively; $\mathrm{HR}=0.696$; $95 \% \mathrm{CI}=0.5$ to $0.9 ; P=0.04)$.

Cows $(\mathrm{n}=296)$ fed HE diets during the CU period lost more BCS during the first 6 wk postpartum $(P=$ 0.04) than cows fed CE diets (Figure 1). Interactions between parity and treatment were not significant. Parity had a significant effect; cows in LAG2 lost more BCS $(P=0.04)$ than cows in LAG1.

Cows classified as thin $(\mathrm{n}=43)$ versus those that were fat $(\mathrm{n}=26)$ at $\mathrm{wk}-4$ prepartum had a longer median DTP (207 and $116 \mathrm{~d}$, respectively; HR = 0.509; $95 \% \mathrm{CI}=0.3$ to $0.9 ; P=0.02)$. At wk 1 postpartum, cows classified as thin $(\mathrm{n}=154)$ had a longer median DTP than cows $(\mathrm{n}=160)$ in moderate BCS (170 and $148 \mathrm{~d}$, respectively; $\mathrm{HR}=0.760 ; 95 \% \mathrm{CI}=0.5$ to 0.9 ; $P=0.05)$; no cows were classified as fat at this time.

Treatment $\mathrm{CE}$ versus $\mathrm{HE}$ diet during the $\mathrm{CU}$ period tended $(P=0.10)$ to have a positive effect on DMI in the first $4 \mathrm{wk}$ postpartum $(\mathrm{LSM} \pm \mathrm{SEM}=16.5 \pm 0.98$ and $15.4 \pm 0.93 \mathrm{~kg}$ for $\mathrm{CE}$ and $\mathrm{HE}$ diets, respectively), with calving season explaining part of the variability in the model $(P<0.01)$. Cows calving during the summer 
Table 3. Final Cox proportional hazard model of the associations of dietary energy intake in the dry period with time from calving to pregnancy in 332 Holstein cows in 7 studies, accounting for experiment as a cluster effect

\begin{tabular}{llccccc}
\hline Variable $^{1}$ & Level & Coefficient & SEM & $\begin{array}{c}\text { Hazard } \\
\text { ratio }\end{array}$ & $95 \%$ CI & $P$-value \\
\hline FO & $\mathrm{HE}^{2}$ & 0.2061 & 0.19 & 1.229 & $0.84-1.80$ & 0.29 \\
CU & $\mathrm{HE}$ & -0.3626 & 0.18 & 0.696 & $0.49-0.99$ & 0.04 \\
Season of calving & & & & & & \\
Spring & & 0.1414 & 0.28 & 1.152 & $0.66-1.99$ & 0.61 \\
Summer & & 0.6807 & 0.26 & 1.975 & $1.18-3.31$ & $<0.01$ \\
$\quad$ Autumn & & 0.5582 & 0.28 & 1.748 & $1.01-3.02$ & 0.04 \\
RPAT & & -0.4411 & 0.16 & 0.643 & $0.47-0.88$ & $<0.01$ \\
\hline
\end{tabular}

${ }^{1} \mathrm{FO}=$ far-off period; $\mathrm{CU}=$ close-up period; RPAT $=$ reproductive pathology (at least 1 of metritis, ovarian cyst, or retained placenta), relative to cows without any of these conditions.

${ }^{2} \mathrm{HE}=$ high-energy diet compared with controlled-energy (CE) diet (see Table 2).

${ }^{3}$ Winter is the referent.

had lower DMI in the first 4 wk postpartum than cows calving in the other seasons of the year $(P<0.01)$. Interactions between calving season and treatment were not significant. Additionally, $\mathrm{CE}$ diet during the FO period had a positive association $(P=0.01)$ with mean $\mathrm{NE}_{\mathrm{LI}}$ in the first 4 wk postpartum compared with $\mathrm{HE}$ diet during the FO period (Figure 2).

Dry period dietary energy regimen was not associated with a greater probability of cows having twins or dystocia $(P>0.4)$. Not surprisingly, cows with twins $(\mathrm{n}=36)$, compared with single-calving cows, had lower HR for DTP $(\mathrm{n}=253$; median $=229$ and $174 \mathrm{~d}$, respectively; $\mathrm{HR}=0.650 ; 95 \% \mathrm{CI}=0.4$ to $1, P=0.06$ ). Days to pregnancy was increased in cows experiencing dystocia $(\mathrm{n}=41)$ compared with non-dystocia cows (n $=163 ;$ median $=217$ and $170 \mathrm{~d}$, respectively; $\mathrm{HR}=$ $0.662 ; 95 \% \mathrm{CI}=0.4$ to $1 ; P=0.07)$. Dietary $\mathrm{NE}_{\mathrm{LI}}$ was not associated with DISE $(P>0.8)$ or $\operatorname{MDISE}(P>$

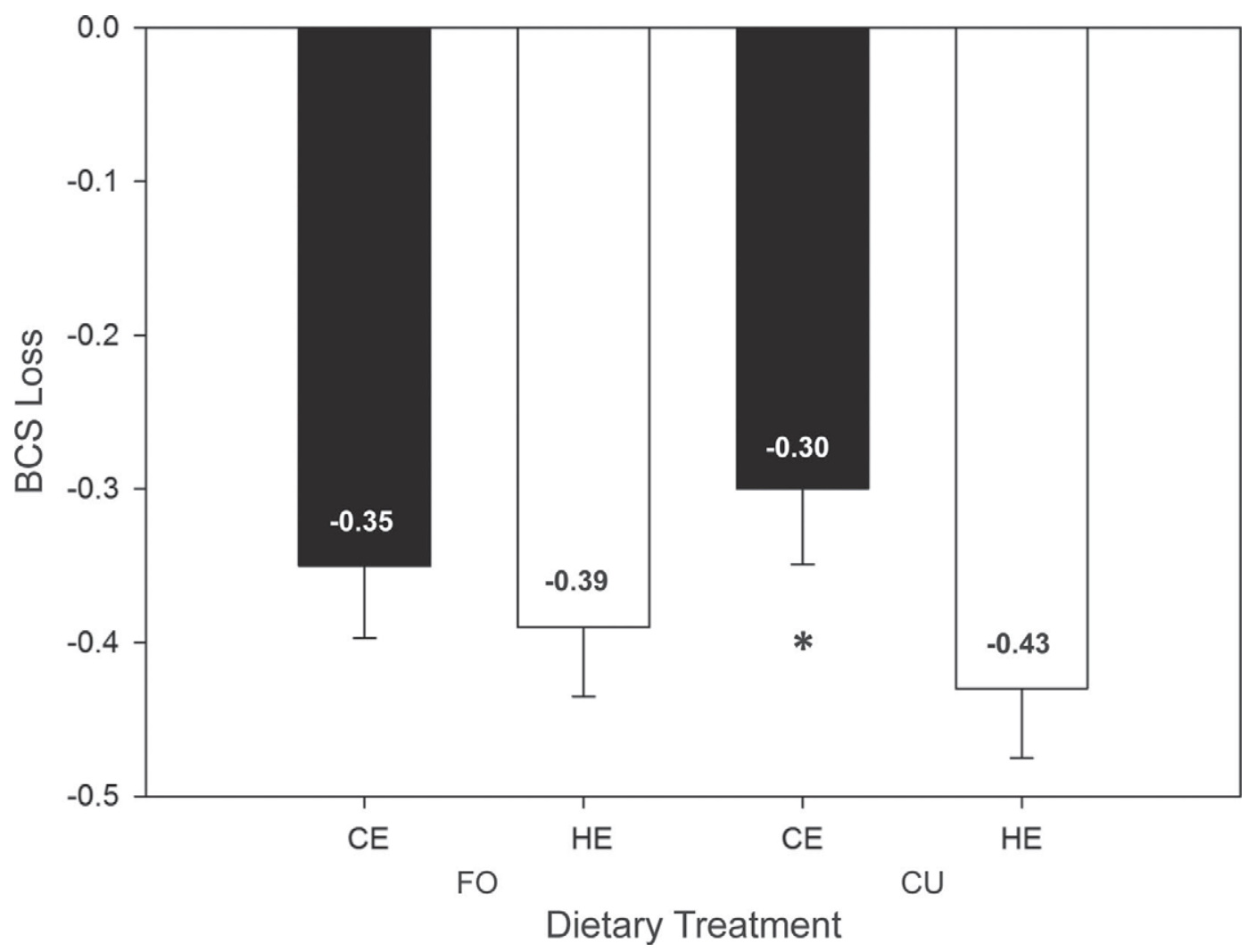

Figure 1. Least squares means and SE for BCS (1 to 5 scale) loss from wk 1 to wk 6 postpartum for cows receiving different dietary treatments prepartum. $\mathrm{CU}=$ close-up period; $\mathrm{FO}=$ far-off period; $\mathrm{HE}=$ high-energy diet; $\mathrm{CE}=$ controlled-energy diet $($ see Table 2$) .{ }^{*} P=0.04$. 


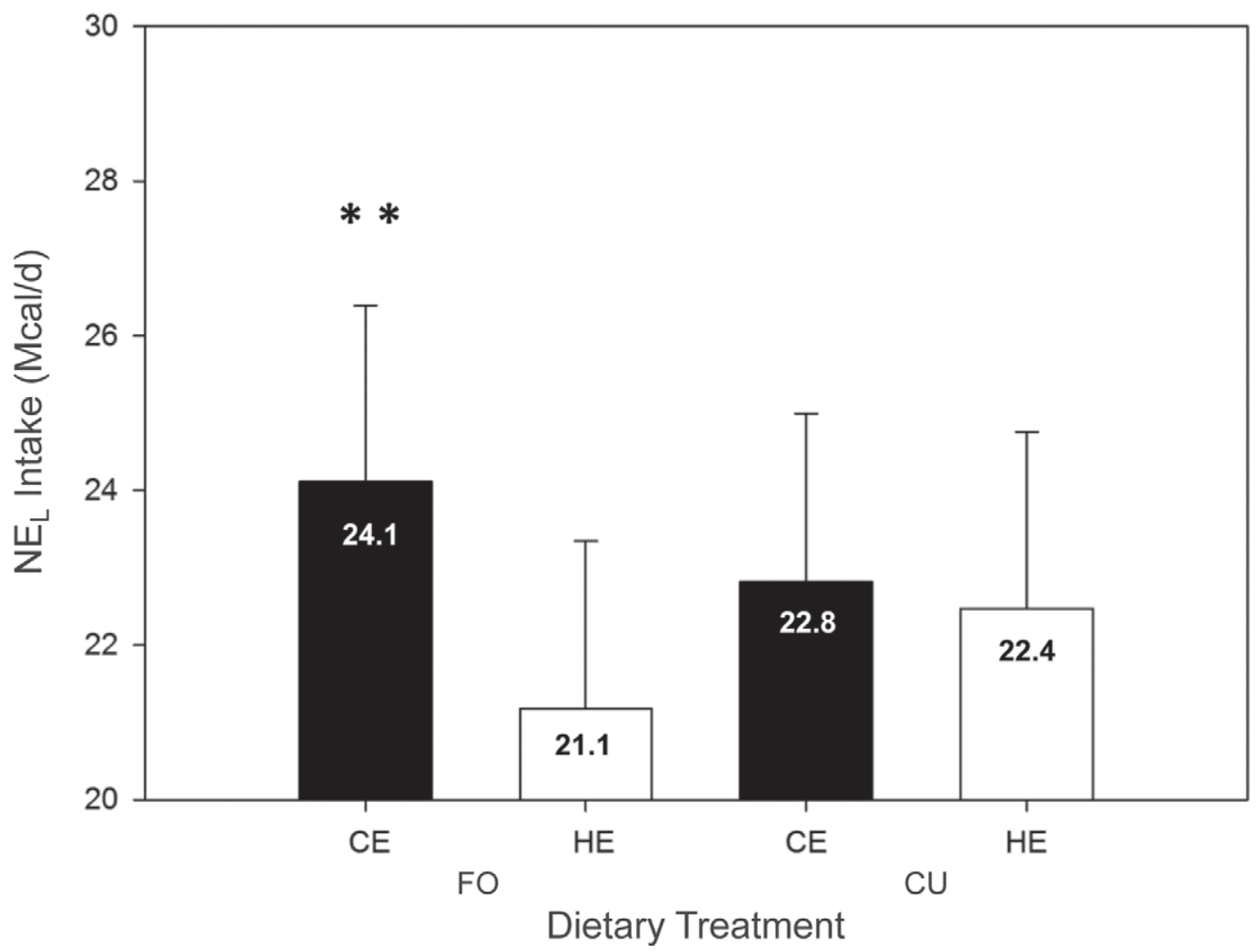

Figure 2. Least squares means and $\mathrm{SE}$ for $\mathrm{NE}_{\mathrm{L}}$ intake (Mcal/d) during the first 4 wk postpartum for cows fed different dietary treatments prepartum. $\mathrm{CU}=$ close-up period; $\mathrm{FO}=$ far-off period; $\mathrm{HE}=$ high-energy diet; $\mathrm{CE}=$ controlled-energy diet $($ see Table 2$) .{ }^{* *} P=0.01$.

0.2). As expected, DISE and MDISE were associated with lower HR for DTP $(P=0.01$ and $P=0.02)$. An interaction between DISE and MDISE with parity was present $(P<0.05)$, as cows in LAG2 were more likely to have disease $(P<0.01)$.

Cows fed $\mathrm{CE}$ diets during the FO period had lower NEFA concentrations during wk 1,2 , and $3(P<0.01)$. However, cows fed $\mathrm{CE}$ diets during the $\mathrm{CU}$ period had higher $(P<0.01)$ NEFA concentrations at wk -2 and -1 before calving (Table 4 ). At wk -1 and wk 1 postpartum, cows in LAG2 had higher concentrations of NEFA than those in LAG1, but no interactions ( $P$ $>0.1$ ) were observed of prepartum diet with parity. Higher NEFA concentrations at wk 1 were associated with a greater probability of DISE $(\mathrm{n}=251$; odds ratio $=1.176 ; 95 \% \mathrm{CI}=1$ to $1.5 ; P<0.03)$.

Cows fed HE diets during the $\mathrm{CU}$ period had greater insulin concentrations at wk -2 and $-1(P<0.01)$ and wk 1 and 2 after calving $(P<0.05)$ compared with cows receiving $\mathrm{CE}$ diets during the same period (Table 4). In contrast, cows fed CE diets during the FO period had higher insulin concentrations at wk 1 and $2(P<$ $0.01)$ than did HE. Parity remained in the model $(P=$ 0.07), showing that cows in LAG1 had higher insulin concentrations than those in LAG2. Higher concentrations of insulin at wk 2 after calving were associated with longer DTP $(P=0.01$; Table 5$)$.

Cows fed HE diets during the CU period had higher glucose concentrations at wk -1 and -2 than cows fed $\mathrm{CE}$ diets $(P<0.01)$. Cows fed $\mathrm{CE}$ diets during the FO period had higher glucose concentration when compared with those fed HE diets at wk $1(P=0.07)$ and wk $3(P=0.02)$ after calving (Table 4$)$. Both prepartum and postpartum, LAG1 cows had higher blood glucose concentrations than LAG2 cows $(P<0.05)$. Higher glucose versus LG in wk 3 (HG n $=154$; LG $\mathrm{n}=206)$ or $4(\mathrm{HG} \mathrm{n}=71$; LG $\mathrm{n}=254)$ after calving was associated with a shorter interval to pregnancy (wk 3 : median $=151$ and $171 \mathrm{~d}$, respectively; $\mathrm{HR}=1.334$; $95 \% \mathrm{CI}=1$ to $1.7 ; P=0.04 ;$ wk 4 : median $=148$ and $167 \mathrm{~d}$, respectively; $\mathrm{HR}=1.394 ; 95 \% \mathrm{CI}=1$ to $1.9 ; P$ $=0.04)$ (Table 5).

Liver total lipid concentrations were higher in cows on the $\mathrm{HE}$ regimen compared with those on the $\mathrm{CE}$ regimen in either segment of the dry period (Table 4). In the first 2 wk after calving, cows receiving $\mathrm{HE}$ diets in the FO period had greater concentrations of total lipid and TG and a greater TG:GLY in the liver com- 
Table 4. Least squares means of blood metabolites and liver composition from Holstein cows fed diets with different energy densities prepartum ${ }^{1}$

\begin{tabular}{|c|c|c|c|c|c|c|c|c|c|}
\hline Variable & Week $^{2}$ & $\mathrm{n}$ & \multicolumn{3}{|c|}{$\mathrm{FO}^{3}$} & \multicolumn{4}{|c|}{$\mathrm{CU}^{4}$} \\
\hline \multicolumn{10}{|l|}{ Blood } \\
\hline \multirow{3}{*}{ NEFA $(\mu \mathrm{Eq} / \mathrm{L})$} & -1 & 349 & 456.05 & 408.10 & 0.14 & 362.60 & 513.27 & 1.12 & $<0.01$ \\
\hline & 1 & 346 & 816.56 & 667.14 & $<0.01$ & 739.96 & 736.20 & 1.17 & 0.93 \\
\hline & 2 & 309 & 617.95 & 508.11 & 0.01 & 597.05 & 525.89 & 1.21 & 0.09 \\
\hline \multirow{3}{*}{ Glucose $(\mathrm{mg} / \mathrm{dL})$} & -1 & 337 & 59.67 & 59.13 & 0.61 & 61.85 & 56.95 & 1.66 & $<0.01$ \\
\hline & 1 & 343 & 55.12 & 57.35 & 0.08 & 57.06 & 55.41 & 1.90 & 0.19 \\
\hline & 3 & 331 & 58.17 & 60.44 & 0.03 & 59.54 & 59.07 & 2.00 & 0.64 \\
\hline \multirow[t]{4}{*}{ Insulin $(\mu \mathrm{IU} / \mathrm{mL})$} & -2 & 312 & 4.43 & 5.15 & 0.15 & 6.92 & 3.30 & 1.25 & $<0.01$ \\
\hline & -1 & 217 & 2.85 & 3.30 & 0.21 & 3.96 & 2.37 & 1.33 & $<0.01^{7}$ \\
\hline & 1 & 315 & 2.79 & 4.10 & $<0.01$ & 3.94 & 2.90 & 1.25 & $<0.01$ \\
\hline & 2 & 293 & 2.73 & 3.89 & $<0.01$ & 3.70 & 2.87 & 1.29 & 0.02 \\
\hline \multirow{2}{*}{ TG (\% wet wt) } & 1 & 181 & 1.90 & 1.26 & 0.02 & 1.66 & 1.44 & 1.31 & 0.38 \\
\hline & 2 & 196 & 2.45 & 1.42 & $<0.01$ & 1.93 & 1.80 & 1.20 & 0.70 \\
\hline \multirow[t]{2}{*}{ GLY (\% wet wt) } & -2 & 159 & 12.91 & 15.52 & 0.38 & 17.04 & 11.77 & 2.74 & 0.06 \\
\hline & 2 & 179 & 7.96 & 9.60 & 0.24 & 7.36 & 10.39 & 1.66 & 0.03 \\
\hline \multirow[t]{3}{*}{ TG:GLY } & -2 & 150 & 0.16 & 0.14 & 0.34 & 0.12 & 0.20 & 1.73 & $<0.01$ \\
\hline & 1 & 125 & 1.20 & 0.61 & 0.03 & 0.85 & 0.86 & 1.46 & 0.98 \\
\hline & 2 & 176 & 1.45 & 0.82 & 0.02 & 1.16 & 1.02 & 1.58 & 0.56 \\
\hline
\end{tabular}

${ }^{1}$ The data are pooled from 7 studies on dietary energy density and intake in the dry period. Least squares means and SEM were back transformed from the natural logarithm for the variables NEFA, insulin, lipids, triglyceride (TG), glycogen (GLY), and TG:GLY.

${ }^{2}$ Weeks relative to calving.

${ }^{3}$ Far-off period.

${ }^{4}$ Close-up period.

${ }^{5} \mathrm{HE}=$ high-energy diet (see Table 2).

${ }^{6} \mathrm{CE}=$ controlled-energy diet (see Table 2).

${ }^{7}$ Interaction $(P=0.07)$; cows fed $\mathrm{CE}$ during $\mathrm{FO}$ and $\mathrm{CU}$ had lower insulin concentration than cows fed HE during FO and CU.

${ }^{8}$ Interaction $(P<0.01)$; cows fed $\mathrm{CE}$ during FO and CU had lower liver fat concentration than cows fed HE during FO and fed CE during CU.

${ }^{9}$ Interaction $(P=0.04)$; cows fed HE during FO and CU had lower liver TG concentration than cows fed CE during FO and CU.

pared with those receiving CE diets (Table 4). At wk 1, cows in LAG2 had higher total lipid and TG concentrations and higher TG:GLY than cows in LAG1. At wk -3 before calving, higher concentrations of total lipid and TG were associated with a longer DTP (total lipid: median $=230$ and $132 \mathrm{~d}$, respectively; $\mathrm{HR}=0.468$; $95 \% \mathrm{CI}=0.2$ to $0.9 ; P=0.02 ;$ TG: median $=208$ and $147 \mathrm{~d}$, respectively; $\mathrm{HR}=0.485 ; 95 \% \mathrm{CI}=0.2$ to 1.1 ; $P=0.11$; Table 5). However, after calving, total lipid and TG concentrations and TG:GLY were associated with higher pregnancy rate (Table 5). Cows fed CE diets during the $\mathrm{CU}$ period had a greater concentration of GLY in the liver postpartum than cows fed HE diets $(P=0.03 ;$ Table 4$)$.

\section{DISCUSSION}

Cows receiving $\mathrm{CE}$ diets in the $\mathrm{CU}$ period had a shorter DTP than cows that consumed energy in excess of requirements in this period (Table 3). Use of CE diets has been a strategy investigated by our group to decrease the overconsumption of energy by formulating rations of relatively low energy density (1.30 to 1.38 Mcal of $\mathrm{NE}_{\mathrm{L}} / \mathrm{kg}$ of $\mathrm{DM}$ ) that cows can consume free choice without greatly exceeding their daily energy requirements. The objective is to feed cows a bulky diet that will just meet their requirements when cows consume feed to rumen fill (Drackley et al., 2007).

An $\mathrm{HR}>1$ indicated that cows fed $\mathrm{CE}$ diets had a higher pregnancy rate (i.e., the time after calving which $50 \%$ of the cows were pregnant was lower) than cows fed HE diets. Parr et al. (1993) found that sheep fed high dietary energy had increased metabolic clearance of progesterone from blood by the liver. Plasma progesterone concentrations were about $25 \%$ lower in heifers fed a high-energy diet compared with those fed a lowenergy diet, perhaps because of greater progesterone clearance (Nolan et al., 1998). Butler (2000) observed 
Table 5. Final Cox proportional hazard model of the associations of blood metabolites and liver composition with days to pregnancy (DTP) in Holstein cows in 7 studies on diet energy density and intake in the dry period, accounting for experiment as a cluster effect

\begin{tabular}{|c|c|c|c|c|c|c|c|c|}
\hline Variable & Week $^{2}$ & $\mathrm{n}$ & Level & Coefficient & SEM & $\begin{array}{c}\text { Hazard } \\
\text { ratio }\end{array}$ & $95 \% \mathrm{CI}$ & $P$-value \\
\hline \multicolumn{9}{|l|}{ Blood } \\
\hline Insulin $(\mu \mathrm{IU} / \mathrm{mL})$ & 2 & 323 & & -0.0453 & 0.02 & 0.956 & $0.92-0.99$ & 0.01 \\
\hline \multicolumn{9}{|l|}{ Liver } \\
\hline Total lipid (\% wet wt) & 4 & 166 & - & 0.0891 & 0.03 & 1.093 & $1.03-1.16$ & $<0.01$ \\
\hline \multirow[t]{4}{*}{ TG (\% wet wt) } & -3 & 131 & $\mathrm{H}$ & -0.7244 & 0.45 & 0.485 & $0.20-1.18$ & 0.11 \\
\hline & & & M & 0.4504 & 0.36 & 1.569 & $0.77-3.17$ & 0.21 \\
\hline & 2 & 226 & - & 0.0645 & 0.02 & 1.067 & $1.01-1.12$ & 0.01 \\
\hline & 4 & 167 & - & 0.1300 & 0.03 & 1.139 & $1.06-1.22$ & $<0.01$ \\
\hline \multirow[t]{2}{*}{ TG:GLY } & 2 & 206 & $\mathrm{H}$ & 0.4642 & 0.22 & 1.591 & $1.03-2.45$ & 0.04 \\
\hline & & & M & 0.5053 & 0.18 & 1.657 & $1.15-2.38$ & 0.01 \\
\hline
\end{tabular}

${ }^{1}$ Glucose classes at wk 3 were based on median values: low: $<60 \mathrm{mg} / \mathrm{dL}$ (L; referent) and high: $>60 \mathrm{mg} / \mathrm{dL}$ (H). Glucose classes at wk 4 were based on median values: low: $<65 \mathrm{mg} / \mathrm{dL}$ (L; referent) and high: $>65 \mathrm{mg} / \mathrm{dL}(\mathrm{H})$. Total lipid at wk -3 classes were based on terciles: low: $<4 \%$ (L; referent), moderate: 4 to $5 \%(\mathrm{M})$, and high: $>5 \%(\mathrm{H})$; total lipid at wk 4 was used as a continuous variable. Triglyceride $(\mathrm{TG})$ at wk -3 classes were based on terciles: low: $<0.5 \%$ (L; referent), moderate: 0.5 to $1 \%(\mathrm{M})$, and high: $1 \%(\mathrm{H})$; TG at wk 2 and 4 was used as a continuous variable. The TG:glycogen (GLY) ratio at wk 2 classes were based on terciles: low: $<0.8$ (L; referent), moderate: 0.8 to 2 (M), and high: $>2$ (H). The TG:GLY ratio at wk 4 classes were based on terciles: low: $<0.1$ (L; referent), moderate: 0.1 to $0.6(\mathrm{M})$, and high: $>0.6(\mathrm{H})$.

${ }^{2}$ Weeks relative to calving.

increased clearance of progesterone and a carryover effect of NEB that resulted in lower plasma progesterone concentration that led to reduced fertility. Lower levels of circulating progesterone around AI (either before or after) were associated with reduced fertility (Sangsritavong et al., 2002). Unfortunately, plasma progesterone concentrations were not analyzed in the current study, but its association with prepartum dietary treatments is worth exploring.

Previous research, besides the experiments included in the current study, has found positive associations between the CE strategy and a smoother transition period. Such improvement would be reflected in better DMI postpartum (Drackley et al., 2005; Beever, 2006) and better health status of cows (Drackley et al., 2005; Drackley et al., 2007; Litherland et al., 2011). In contrast to other studies in which CE dietary management in the FO period had greater postpartum benefits than its effect in the CU period (Dann et al., 2006; Richards, 2011), in the present analysis of 7 similar studies, limitation of energy intake through CE dietary management in approximately the last 3 wk before calving, but not in the FO period, was associated with improved reproductive performance.

Successful implementation of the CE diets is critical (Drackley et al., 2007). The CE diets had longer particle size, which reflects the high-bulk strategy to reduce the dietary energy density in some experiments. In diets with NDF $>50 \%$ of total DM, excessive particle size can lead to intake depression or to sorting against longer forage particles (NRC, 2001), which could accentuate excessive energy intake in some animals and leave inadequate energy, starch, or NFC for others in a group. In the studies used here using tie-stalls or feeding gates, there was no competition for feed access.

The mechanisms that may underlie the association between $\mathrm{CE}$ diets during the $\mathrm{CU}$ period and better reproductive performance are inconclusive. In the present analysis, it was the $\mathrm{CE}$ diet fed during the FO period rather than the $\mathrm{CU}$ period that was associated with greater $\mathrm{NE}_{\mathrm{LI}}$ in the first 4 wk postpartum (24.1 vs. $21.1 \mathrm{Mcal} / \mathrm{d}$ ). Feeding the CE diet during the FO (but not CU) period was associated with modestly increased plasma glucose concentration at wk 3 postpartum (Table 4), at which time above-median glucose concentration was associated with increased pregnancy rate.

Perhaps the effects of preventing excessive nutrient intake during the FO period are diminished until early postpartum (first $10 \mathrm{DIM}$ ), when most of the metabolic changes are seen (Dann et al., 2006). Therefore, the effect of $\mathrm{CE}$ diets during the $\mathrm{CU}$ period would be responsible for achieving an effect later in lactation, when reproductive performance would be measured.

Holcomb et al. (2001) studied different amount of forages in ad libitum and restricted prepartum regimens for Holstein cows and found that restricted feeding resulted in greater DMI postpartum compared with freechoice feeding prepartum. Higher energy intake in the 
first 4 wk postpartum may result in less NEB, as the relationship between milk production and $\mathrm{NE}_{\mathrm{LI}}$ is alleviated in this time period when cows are able to have higher DMI compared with previous weeks (Gerloff, 2000; Hayirli et al., 2002). Time to the NEB nadir has been positively associated with time to first ovulation (Beam and Butler, 1999; Butler, 2000). A shorter delay to first ovulation may be positively related to higher conception rates (Butler, 2000). In addition, cows fed $\mathrm{CE}$ diets during the FO period had less BCS loss in the first 6 wk postpartum (Figure 1). Villa-Godoy et al. (1988) suggested that energy intake is the main factor reflecting the degree of body energy loss in early lactation. Butler and Smith (1989) showed that cows losing $<1$ BCS unit between calving and first insemination had a mean probability of pregnancy at first AI of $53 \%$ compared with $17 \%$ for cows losing $>1$ BCS unit (on a $1=$ thin to $5=$ obese scale). In Ireland, a pasturebased system with a fixed breeding calendar, it was found that BCS loss should be limited to 0.5 units to avoid detrimental effects on reproductive performance (Buckley et al., 2003).

Cows consuming HE diets had greater concentrations of NEFA in wk 1 postpartum (Table 4). Higher NEFA concentrations postpartum were associated with increased risk of cows becoming ill (Cameron et al., 1998; LeBlanc et al., 2005; Ospina et al., 2010). Not surprisingly, cows with 1 or more clinical disease occurrences had poorer reproductive success in our study, similar to research by others (Curtis et al., 1985; Halpern et al., 1985; Sheldon et al., 2006). Cows receiving CE diets during the CU period had higher NEFA concentrations than those receiving HE diets, although NEFA concentrations were not associated with pregnancy rate in the present analysis. However, cows fed $\mathrm{CE}$ diets could be better adapted to use NEFA as a metabolic fuel after parturition (Friggens et al., 2004; Janovick et al., 2011).

Higher concentrations of glucose at wk 3 for the group fed $\mathrm{CE}$ diets during the FO period, although modest, were correlated with shorter time to pregnancy (Table 4). Higher blood glucose concentration has been associated with improved fertility in Holstein cows (Plym Forshell et al., 1991). Higher blood glucose concentration may reflect greater energy intake in early lactation by cows previously fed $\mathrm{CE}$ diets during the FO period (Figure 2). Cows that received $\mathrm{HE}$ diets during the $\mathrm{CU}$ period had higher blood glucose concentrations prepartum, as expected from the higher energy intake regimen (Table 4).

Modestly higher insulin concentrations postpartum for cows receiving $\mathrm{CE}$ diets during the $\mathrm{FO}$ period may be associated with better glucose uptake and, again, a reflection of higher $\mathrm{NE}_{\mathrm{LI}}$ postpartum. Yet, increased insulin concentration at wk 2 was associated with slightly longer DTP. Other studies have shown that greater NEB during early lactation was associated with a lower concentration of plasma insulin in early lactation, and prolonged intervals from calving to first ovulation (Beam and Butler, 1997; Beam and Butler, 1999). Gong et al. (2002) showed that dietary induction of increased insulin concentration reduced time to first ovulation. Nevertheless, subsequent fertility parameters, including pregnancy to first service and number of services required per pregnancy, were not affected by diet; further work was suggested to determine the effects of the dietary treatment on fertility. Whether the large increase of plasma NEFA concentrations in HE-fed cows around calving was simply a consequence of greater body fat storage in the dry period or an effect of different insulin sensitivity and responsiveness in muscle and adipose tissues between cows with different BCS cannot be answered by the present work and requires further investigation.

Despite a reduced blood glucose concentration, Radcliff et al. (2006) observed that cows feed restricted during the early postpartum period did not have reduced blood insulin concentration. This profile can be compared with that of type 2 diabetes in humans, where there is no absolute insulin deficiency. Instead, impaired insulin action is thought to be the primary event. Schoenberg et al. (2012) found similar results when comparing dry cows fed at high or low energy intakes. After glucose tolerance tests and hyperinsulinemic-euglycemic clamps, cows fed below energy requirements had greater reduction in plasma NEFA concentration, greater NEFA clearance rate, and greater area under the curve during glucose tolerance tests, indicating that those cows had lower insulin resistance related to lipid metabolism. In addition, Kerestes et al. (2009) showed that severe inflammatory diseases, such as puerperal metritis, with intensive release of proinflammatory cytokines potentially depress insulin secretion and decrease whole-body insulin responsiveness in dairy cows, with long-term effects on metabolism and reproduction. Cows receiving HE diets during the CU period had lower concentrations of glucose and insulin at wk 1 compared with cows receiving CE diets (Table 4). Whether cows receiving HE diets would have greater insulin resistance during the transition period is yet to be determined.

Higher hepatic total lipid concentration at wk -3 was associated with a lower daily probability of pregnancy (Table 5). Cows receiving HE diets during the FO and $\mathrm{CU}$ periods versus $\mathrm{CE}$ diets for the same periods had higher total lipid concentrations in the liver. Drackley et al. (1991) suggested that an excess of energy consumption prepartum could later lead to increased lipid accumulation in the liver as a result of inability either 
to oxidize or export the increased mobilized NEFA. The association of liver lipid accumulation and infertility has been explored before (Wensing et al., 1997). An in vitro approach showed that oocytes harvested between 80 and $140 \mathrm{~d}$ postpartum had a decreased development capacity in cows with induced hepatic lipidosis postpartum.

Interestingly, higher total lipid concentration and higher TG:GLY in liver after calving were weakly associated with better reproductive performance. One explanation could be that, in the present study, the maximum total liver lipid concentration was $12 \%$ (wet basis) during the transition period. According to Gaal et al. (1983), cows could be biochemically classified as having mild fatty liver with total lipid concentrations from 8 to $13 \%$, and more than $13 \%$ as moderate, with the latter representing damage to liver cells. In our data, cows classified as having high values for liver lipid might reflect cows with greater intake and greater capacity to metabolize circulating fuels because the hepatic lipid infiltration was mild. Epidemiological research, using different locations (herds), with a larger variation in values for liver lipid and TG [such as the one performed by Jorritsma et al. (2000)] would be better suited to investigate the associations between reproductive success and liver lipid infiltration. In that study, the authors concluded that differences in NEB or the accumulation of TG in the liver of postpartum dairy cows affects reproductive performance.

Another factor to be considered is the fact that cows have an individual variation in liver size that can be misleading when liver biopsy is used to determine the physiological capacity of the liver (Haudum et al., 2011). Rukkwamsuk et al. (1999) was unable to show a statistical difference in time to first ovulation after calving between cows treated with high-energy diet or a control diet to meet energy requirements. However, when the data were pooled and separated by liver TG content, a positive correlation was observed between TG and days to first ovulation. The mechanism by which TG could have affected reproduction remained unclear. Cows that maintained low TG concentrations between 6 to $17 \mathrm{~d}$ postpartum and produced more milk had better or equal fertility results than cows with comparable levels of TG producing less milk (Jorritsma et al., 2000). Those results could suggest that individual cow variation regarding liver oxidative, storage, and export capacity has an important role in liver fat measurement as a reflection of a cow's adaptation to the onset of lactation.

Cows fed CE diets had greater hepatic glycogen concentrations at wk 2, similar to findings by Van den Top et al. (1996). In the present study, we did not find any association between glycogen and DTP. Harrison et al.
(1990) found that high-producing cows $(10,814 \mathrm{~kg}, 305-$ d mature equivalent), in contrast to average producing cows $(6,912 \mathrm{~kg})$, had lower hepatic glycogen content and suggested that it was involved in regulating time to first detected estrus and to pregnancy, which both occurred much later in the high-production group. Higher liver glycogen possibly was associated with better DMI (Grum et al., 2002) and a more available source of energy for reproductive function (Harrison et al., 1990).

\section{CONCLUSIONS}

Cows that received $\mathrm{CE}$ diets during the last $3 \mathrm{wk}$ prepartum had shorter DTP than cows that consumed HE diets in this time period, which may be attributable in part to increased $\mathrm{NE}_{\mathrm{LI}}$ in the first 4 wk postpartum for cows that received $\mathrm{CE}$ diets in the $\mathrm{CU}$ period. In addition, lower BCS loss in the first 6 wk and slightly greater glucose concentrations at wk 3 may have contributed to improved reproductive performance. Energy-limited cows had lower liver TG concentrations at wk -2 , which led to fewer DTP. A strategy of CE prepartum may have a favorable impact on both health and reproductive performance. Research evaluating the effect of $\mathrm{CE}$ diets prepartum on more specific reproduction variables, such as progesterone concentrations, ovarian function, time to first ovulation, and embryonic death, is needed.

\section{ACKNOWLEDGMENTS}

This project was partially supported by Pfizer Animal Health (Kalamazoo, MI). The authors are grateful for the University of Illinois (Urbana) researchers, veterinarians, and the Dairy Research Unit staff involved in the collection of the data.

\section{REFERENCES}

Allison, P. D. 2010. Survival Analysis Using SAS ${ }^{\circledR}$ : A Practical Guide. 2nd ed. SAS Inst. Inc., Cary, NC.

Bauman, D. E. 2000. Regulation of nutrient partitioning during lactation: Homeostasis and homeorhesis revisited. Pages 311-328 in Ruminant Physiology: Digestion, Metabolism, Growth and Reproduction. P. B. Cronjé, ed. CABI Publishing, Wallingford, UK.

Beam, S. W., and W. R. Butler. 1997. Energy balance and ovarian follicle development prior to the first ovulation postpartum in dairy cows receiving three levels of dietary fat. Biol. Reprod. $56: 133-142$.

Beam, S. W., and W. R. Butler. 1999. Effects of energy balance on follicular development and first ovulation in postpartum dairy cows. J. Reprod. Fertil. Suppl. 54:411-424.

Beever, D. E. 2006. The impact of controlled nutrition during the dry period on dairy cow health, fertility and performance. Anim. Reprod. Sci. 96:212-226.

Bell, A. W. 1995. Regulation of organic nutrient metabolism during transition from late pregnancy to early lactation. J. Anim. Sci. 73:2804-2819.

Buckley, F., K. O'Sullivan, J. F. Mee, R. D. Evans, and P. Dillon. 2003. Relationships among milk yield, body condition, cow weight, 
and reproduction in spring-calved Holstein-Friesians. J. Dairy Sci. $86: 2308-2319$.

Butler, W. R. 2000. Nutritional interactions with reproductive performance in dairy cattle. Anim. Reprod. Sci. 60-61:449-457.

Butler, W. R., and R. D. Smith. 1989. Interrelationships between energy balance and postpartum reproductive function in dairy cattle. J. Dairy Sci. 72:767-783.

Cameron, R. E., P. B. Dyk, T. H. Herdt, J. B. Kaneene, R. Miller, H. F. Bucholtz, J. S. Liesman, M. J. VandeHaar, and R. S. Emery. 1998. Dry cow diet, management, and energy balance as risk factors for displaced abomasum in high producing dairy herds. J. Dairy Sci. 81:132-139.

Carlson, D. B., J. W. McFadden, A. D'Angelo, J. C. Woodworth, and J. K. Drackley. 2007. Dietary L-carnitine affects periparturient nutrient metabolism and lactation in multiparous cows. J. Dairy Sci. 90:3422-3441.

Colman, D. R., D. E. Beever, R. W. Jolly, and J. K. Drackley. 2011. Commentary: Gaining from technology for improved dairy cow nutrition: Economic, environmental, and animal health benefits. Prof. Anim. Sci. 27:505-517.

Curtis, C. R., H. N. Erb, C. J. Sniffen, R. D. Smith, and D. S. Kronfeld. 1985. Path analysis of dry period nutrition, postpartum metabolic and reproductive disorders, and mastitis in Holstein cows. J. Dairy Sci. 68:2347-2360.

Dann, H. M., N. B. Litherland, J. P. Underwood, M. Bionaz, A. D'Angelo, J. W. McFadden, and J. K. Drackley. 2006. Diets during far-off and close-up dry periods affect periparturient metabolism and lactation in multiparous cows. J. Dairy Sci. 89:3563-3577.

Dann, H. M., D. E. Morin, G. A. Bollero, M. R. Murphy, and J. K. Drackley. 2005. Prepartum intake, postpartum induction of ketosis, and periparturient disorders affect the metabolic status of dairy cows. J. Dairy Sci. 88:3249-3264.

Douglas, G. N., T. R. Overton, H. G. Bateman II, H. M. Dann, and J. K. Drackley. 2006. Prepartal plane of nutrition, regardless of dietary energy source, affects periparturient metabolism and dry matter intake in Holstein cows. J. Dairy Sci. 89:2141-2157.

Douglas, G. N., T. R. Overton, H. G. Bateman, and J. K. Drackley. 2004. Peripartal metabolism and production of Holstein cows fed diets supplemented with fat during the dry period. J. Dairy Sci. $87: 4210-4220$.

Drackley, J. K., H. M. Dann, N. A. Janovick, N. B. Litherland, J. P. Underwood, and J. J. Loor. 2005. Physiological and pathological adaptations in dairy cows that may increase susceptibility to periparturient diseases and disorders. Ital. J. Anim. Sci. 4:323-344.

Drackley, J. K., H. M. Dann, and N. A. Janovick Guretzky. 2007. New concepts for feeding dry cows. Pages $17-28$ in Proc. Tri-State Dairy Nutr. Conf., Fort Wayne, IN. M. Eastridge, ed. Ohio State University, Columbus.

Drackley, J. K., J. J. Veenhuizen, M. J. Richard, and J. W. Young. 1991. Metabolic changes in blood and liver of dairy cows during either feed restriction or administration of 1,3-butanediol. J. Dairy Sci. 74:4254-4264

Ferguson, J. D., D. T. Galligan, and N. Thomsen. 1994. Principal descriptors of body condition score in Holstein cows. J. Dairy Sci. 77:2695-2703.

Fletcher, M. J. 1968. A colorimetric method for estimating serum triglycerides. Clin. Chim. Acta 22:393-397.

Foster, L. B., and R. T. Dunn. 1973. Stable reagents for determination of serum triglycerides by a colorimetric Hantzsch condensation method. Clin. Chem. 19:338-340.

Friggens, N. C., J. B. Andersen, T. Larsen, O. Aaes, and R. J. Dewhurst. 2004. Priming the dairy cow for lactation: A review of dry cow feeding strategies. Anim. Res. 53:453-473.

Gaal, T., I. M. Reid, R. A. Collins, C. J. Roberts, and B. V. Pike. 1983 Comparison of biochemical and histological methods of estimating fat content of liver of dairy cows. Res. Vet. Sci. 34:245-248.

Gerloff, B. J. 2000. Dry cow management for the prevention of ketosis and fatty liver in dairy cows. Vet. Clin. North Am. Food Anim. Pract. 16:283-292.

Gong, J. G., W. J. Lee, P. C. Garnsworthy, and R. Webb. 2002. Effect of dietary-induced increases in circulating insulin concentrations during the early postpartum period on reproductive function in dairy cows. Reproduction 123:419-427.

Gröhn, Y. T., S. W. Eicker, V. Ducrocq, and J. A. Hertl. 1998. Effect of diseases on the culling of Holstein dairy cows in New York State. J. Dairy Sci. 81:966-978.

Gröhn, Y. T., and P. J. Rajala-Schultz. 2000. Epidemiology of reproductive performance in dairy cows. Anim. Reprod. Sci. 6061:605-614.

Grum, D. E., J. K. Drackley, and J. H. Clark. 2002. Fatty acid metabolism in liver of dairy cows fed supplemental fat and nicotinic acid during an entire lactation. J. Dairy Sci. 85:3026-3034.

Grum, D. E., J. K. Drackley, R. S. Younker, D. W. LaCount, and J. J. Veenhuizen. 1996. Nutrition during the dry period and hepatic lipid metabolism of periparturient dairy cows. J. Dairy Sci. 79:1850-1864.

Grummer, R. R. 2008. Nutritional and management strategies for the prevention of fatty liver in dairy cattle. Vet. J. 176:10-20.

Halpern, N. E., H. N. Erb, and R. D. Smith. 1985. Duration of retained placenta and subsequent fertility in dairy cows. Theriogenology 23:807-813.

Hammon, D. S., I. M. Evjen, T. R. Dhiman, J. P. Goff, and J. L. Walters. 2006. Neutrophil function and energy status in Holstein cows with uterine health disorders. Vet. Immunol. Immunopathol. $113: 21-29$

Hara, A., and N. S. Radin. 1978. Lipid extraction of tissues with a low-toxicity solvent. Anal. Biochem. 90:420-426.

Harrison, R. O.. S. P. Ford, J. W. Young, A. J. Conley, and A. E. Freeman. 1990. Increased milk production versus reproductive and energy status of high producing dairy cows. J. Dairy Sci. $73: 2749-2758$

Haudum, A., A. Starke, M. Beyerbach, P. Wohlsein, and J. Rehage. 2011. Ultrasonographic assessment of liver dimensions in dairy cows with different hepatic triglyceride content. J. Anim. Sci 89:1392-1400

Hayirli, A., R. R. Grummer, E. V. Nordheim, and P. M. Crump. 2002. Animal and dietary factors affecting feed intake during the prefresh transition period in Holsteins. J. Dairy Sci. 85:3430-3443.

Herbein, J. H., R. J. Aiello, L. I. Eckler, R. E. Pearson, and R. M. Akers. 1985. Glucagon, insulin, growth hormone, and glucose concentrations in blood plasma of lactating dairy cows. J. Dairy Sci. $68: 320-325$.

Holcomb, C. S., H. H. Van Horn, H. H. Head, M. B. Hall, and C. J. Wilcox. 2001. Effects of prepartum dry matter intake and forage percentage on postpartum performance of lactating dairy cows. J. Dairy Sci. 84:2051-2058.

Hughes, J. P. 1962. A simplified instrument for obtaining liver biopsies in cattle. Am. J. Vet. Res. 23:1111-1113.

Huzzey, J. M., D. M. Veira, D. M. Weary, and M. A. G. von Keyserlingk. 2007. Prepartum behavior and dry matter intake identify dairy cows at risk for metritis. J. Dairy Sci. 90:3220-3233.

Janovick, N. A., Y. R. Boisclair, and J. K. Drackley. 2011. Prepartum dietary energy intake affects metabolism and health during the periparturient period in primiparous and multiparous Holstein cows. J. Dairy Sci. 94:1385-1400.

Janovick, N. A., and J. K. Drackley. 2010. Prepartum dietary management of energy intake affects postpartum intake and lactation performance by primiparous and multiparous Holstein cows. J. Dairy Sci. 93:3086-3102.

Johnson, M. M., and J. P. Peters. 1993. Technical note: An improved method to quantify nonesterified fatty acids in bovine plasma. J. Anim. Sci. 71:753-756.

Jorritsma, R., H. Jorritsma, Y. H. Schukken, and G. H. Wentink. 2000. Relationships between fatty liver and fertility and some periparturient diseases in commercial Dutch dairy herds. Theriogenology 54:1065-1074.

Jorritsma, R., T. Wensing, T. A. Kruip, P. L. Vos, and J. P. Noordhuizen. 2003. Metabolic changes in early lactation and impaired reproductive performance in dairy cows. Vet. Res. 34:11-26.

Kerestes, M., V. Faigl, M. Kulcsár, O. Balogh, J. Földi, H. Fébel, Y. Chilliard, and G. Huszenicza. 2009. Periparturient insulin secretion and whole-body insulin responsiveness in dairy cows showing 
various forms of ketone pattern with or without puerperal metritis. Domest. Anim. Endocrinol. 37:250-261.

Kunz, P. L., J. W. Blum, I. C. Hart, H. Bickel, and J. Landis. 1985. Effects of different energy intakes before and after calving on foodintake, performance and blood hormones and metabolites in dairy cows. Anim. Prod. 40:219-231.

LeBlanc, S. J., K. E. Leslie, and T. F. Duffield. 2005. Metabolic predictors of displaced abomasum in dairy cattle. J. Dairy Sci. 88:159-170.

Leroy, J. L. M. R., T. Vanholder, B. Mateusen, A. Christophe, G. Opsomer, A. de Kruif, G. Genicot, and A. Van Soom. 2005. Nonesterified fatty acids in follicular fluid of dairy cows and their effect on developmental capacity of bovine oocytes in vitro. Reproduction 130:485-495.

Litherland, N. B., H. M. Dann, and J. K. Drackley. 2011. Prepartum nutrient intake alters palmitate metabolism by liver slices from peripartal dairy cows. J. Dairy Sci. 94:1928-1940.

Littell, R. C., W. W. Stroup, and R. J. Freund. 2002. SAS for Linear Models. 4th ed. SAS Institute Inc., Cary, NC.

Lo, S., J. C. Russell, and A. W. Taylor. 1970. Determination of glycogen in small tissue samples. J. Appl. Physiol. 28:234-236.

Lucy, M. C. 2001. Reproductive loss in high-producing dairy cattle: Where will it end? J. Dairy Sci. 84:1277-1293.

Moreira, F., C. Orlandi, C. A. Risco, R. Mattos, F. Lopes, and W. W. Thatcher. 2001. Effects of presynchronization and bovine somatotropin on pregnancy rates to a timed artificial insemination protocol in lactating dairy cows. J. Dairy Sci. 84:1646-1659.

NRC. 2001. Nutrient Requirements of Dairy Cattle. 7th rev. ed. Natl. Acad. Press, Washington, DC.

Nolan, R., D. O'Callaghan, R. T. Duby, P. Lonergan, and M. P. Boland. 1998. The influence of short-term nutrient changes on follicle growth and embryo production following superovulation in beef heifers. Theriogenology 50:1263-1274.

Ospina, P. A., D. V. Nydam, T. Stokol, and T. R. Overton. 2010. Evaluation of nonesterified fatty acids and $\beta$-hydroxybutyrate in transition dairy cattle in the northeastern United States: Critical thresholds for prediction of clinical diseases. J. Dairy Sci. 93:546-554.

Parr, R. A., I. F. Davis, M. A. Miles, and T. J. Squires. 1993. Feed intake affects metabolic clearance rate of progesterone in sheep. Res. Vet. Sci. 55:306-310.

Peterson, J. I., and D. S. Young. 1968. Evaluation of the hexokinase/ glucose-6-phosphate dehydrogenase method of determination of glucose in urine. Anal. Biochem. 23:301-316.

Plym Forshell, K., L. Andersson, and B. Pehrson. 1991. The relationships between the fertility of dairy cows and clinical and biochemical measurements, with special reference to plasma glucose and milk acetone. Zentralbl. Veterinärmed. A 38:608-616.

Pursley, J. R., M. O. Mee, and M. C. Wiltbank. 1995. Synchronization of ovulation in dairy cows using $\mathrm{PGF}_{2 \alpha}$ and $\mathrm{GnRH}$. Theriogenology 44:915-923.

Radcliff, R. P., B. L. McCormack, D. H. Keisler, B. A. Crooker, and M. C. Lucy. 2006. Partial feed restriction decreases growth hor- mone receptor $1 \mathrm{~A}$ mRNA expression in postpartum dairy cows. J. Dairy Sci. 89:611-619.

Richards, B. F. 2011. Strategies to decrease incidence of fatty liver in dairy cows. PhD Diss. University of Illinois, Urbana.

Rukkwamsuk, T., T. Wensing, and T. A. M. Kruip. 1999. Relationship between triglyceride concentration in the liver and first ovulation in postpartum dairy cows. Theriogenology 51:1133-1142.

Sangsritavong, S., D. K. Combs, R. Sartori, L. E. Armentano, and M. C. Wiltbank. 2002. High feed intake increases liver blood flow and metabolism of progesterone and estradiol-17 $\beta$ in dairy cattle. J. Dairy Sci. 85:2831-2842.

Santos, J. E. P., T. R. Bilby, W. W. Thatcher, C. R. Staples, and F. T. Silvestre. 2008. Long chain fatty acids of diet as factors influencing reproduction in cattle. Reprod. Domest. Anim. 43(Suppl. 2):23-30.

Schoenberg, K. M., R. M. Ehrhardt, and T. R. Overton. 2012. Effect of plane of nutrition and feed deprivation on insulin responses in dairy cattle during late gestation. J. Dairy Sci. 95:670-682.

Sheldon, I. M., G. S. Lewis, S. LeBlanc, and R. O. Gilbert. 2006. Defining postpartum uterine disease in cattle. Theriogenology 65:1516-1530.

St-Pierre, N. R. 2001. Invited review: Integrating quantitative findings from multiple studies using mixed model methodology. J. Dairy Sci. 84:741-755.

Studer, V. A., R. R. Grummer, S. J. Bertics, and C. K. Reynolds. 1993. Effect of prepartum propylene glycol administration on periparturient fatty liver in dairy cows. J. Dairy Sci. 76:2931-2939.

Trinder, P. 1969. Determination of blood glucose using 4-amino phenazone as oxygen acceptor. J. Clin. Pathol. 22:246.

Urton, G., M. A. G. von Keyserlingk, and D. M. Weary. 2005. Feeding behavior identifies dairy cows at risk for metritis. J. Dairy Sci. 88:2843-2849.

Van den Top, A. M., M. J. Geelen, T. Wensing, G. H. Wentink, A. T. Van 't Klooster, and A. C. Beynen. 1996. Higher postpartum hepatic triglyceride concentrations in dairy cows with free rather than restricted access to feed during the dry period are associated with lower activities of hepatic glycerolphosphate acyltransferase. J. Nutr. 126:76-85.

Villa-Godoy, A., T. L. Hughes, R. S. Emery, L. T. Chapin, and R. L. Fogwell. 1988. Association between energy balance and luteal function in lactating dairy cows. J. Dairy Sci. 71:1063-1072.

Walsh, R. B., J. S. Walton, D. F. Kelton, S. J. LeBlanc, K. E. Leslie, and T. F. Duffield. 2007. The effect of subclinical ketosis in early lactation on reproductive performance of postpartum dairy cows. J. Dairy Sci. 90:2788-2796.

Wensing, T., T. Kruip, M. J. H. Geelen, G. H. Wentink, and A. M. van den Top. 1997. Postpartum fatty liver in high-producing dairy cows in practice and in animal studies. The connection with health, production and reproduction problems. Comp. Haematol. Int. $7: 167-171$. 